\title{
THE SETTLEMENT OF CONTRACT NEGOTIATION DISPUTES: A COMPARISON OF PROPOSED LEGISLATION
}

\author{
JOHN S. FORSYTHE*
}

The problem of finding a procedure which will minimize mass work stoppages resulting from the failure to settle labor contract-negotiation disputes by collective bargaining has become of extreme importance to our national well-being since the end of the fighting in August, 1945. Even before V-J Day, the President and the Secretary of Labor, recognizing the possibility of serious industrial disputes in the reconversion period, were considering the advisability of calling a conference of the leaders of labor and management to discuss methods of reducing the major causes of industrial strife. ${ }^{1}$. The decision was crystallized when the Secretary received a letter from Senator Arthur H. Vandenburg on July 30, 1945, suggesting that a National Labor-Management Conference be held to "lay the groundwork for peace with justice on the home front."

In the more than three months between V-J Day and the conclusion of the conference, $^{8}$ the administration resisted pressure for new labor legislation ${ }^{4}$ in the expectation that the conference would recommend a solution to the problem.

Three days after the leaders of labor and management failed to agree upon any procedure to minimize work stoppages, the President requested the Congress to authorize the appointment of emergency fact-finding boards. ${ }^{6}$ The Congress, however, refused to pass H. R. 4908, the Labor Fact-Finding Boards Act, and substituted,

- LL.B., 1939, Duke University School of Law. Member of the District of Columbia and Virginia Bars. Attorney, Legislative and Bureau Service Section, Office of the Solicitor, U. S. Department of Labor.

This article constitutes the opinion of the writer and does not represent official views of the United States Department of Labor.

The President's National Labor-Managenent Conference, D. L. S. Bull. No. 77 (U. S. Dept. Labor 1946) 30 .

Id. at 29.

The Conference met from November 5, 1945, through November 30, 1945. It was composed of thirty-nine members representing the United States Chamber of Commerce, the National Association of Manufacturers, the American Federation of Labor, the Congress of Industrial Organizations, the United Mine Workers of America, the Railway Brotherhoods, and the public. Id. at 32.

'In this period there were serious strikes in oil, coal, lumber, glass, textiles, trucking, and automobiles. (I946) 63 MO. IAB. Rev. 874-876.

"Secretary Schwellenbach testified before the House Labor Committee: "As you all know, 1 took the position, after the conclusion of the war, and it was the position of the Administration, that we should not propose legislation; that we should get these representatives of management and of labor together and let them work out some procedure by which industrial strife could be minimized." Hearings before Committee on Labor on H. R. 4908, 79th Cong., Ist Sess. 130 (1945).

- H. R. Doc. No. 381, 79th Cong., Ist Sess. (1945). 
instead, the provisions of the so-called Case bill, which met with a veto on June II, 1946.?

The year following V-J Day shows the worst record of labor-management conflicts in the history of the United States. ${ }^{8}$ It is not surprising, therefore, that the demand for a legislative solution to the problem has become overwhelming. ${ }^{9}$ President Truman warned of this possibility when he opened the Labor-Management Conference with this admonition: "If the people do not find the answers [to industrial strife] here, they will find them some place else. For these answers must and will be found. The whole system of private enterprise and individual opportunity depends upon finding them."10

The scope of this article, as is indicated by the title, includes only those proposals which deal directly with the problem of minimizing or preventing strikes arising out of labor contract negotiation disputes. ${ }^{11}$ Proposals designed to remove specific issues from the area of collective bargaining, ${ }^{12}$ to restrict union power, ${ }^{13}$ and to regulate strikes over issues other than contract negotiation disputes ${ }^{14}$ will not be discussed at any length. ${ }^{15}$

The main body of the article has been divided into two sections. In the first a number of representative proposals ${ }^{16}$ have been summarized in considerable detail; others have been mentioned briefly to give some indication of their place in the legislative pattern. In the second section common factors have been drawn from the various proposals to give a comparison of the procedures which have been suggested for the settlement of labor contract negotiation disputes.

'See note 19, infra, for a short summary of the legislative history of H. R. 4908.

(1946) 63 Mo. Lab. Rev. 872.

- A recent Gallup Poll indicated that $66 \%$ of the persons questioned were in favor of new laws to control labor unions. Washington Post, Nov. 10, r946, Sec. B., p. 1, col. 4. The Fortune Survey published in November 1946 showed that a startling $27.9 \%$ of the people favored a complete prohibition of all strikes for any reason whatever. Fortune, Nov., 1946, p. 10.

${ }^{20}$ The President's National Labor-Management Conference, D. L. S. Bull. No. 77 (U. S. Dept. Labor 1946) 40.

${ }^{12}$ With a few exceptions such proposals would set up machinery for one or more of the following procedures: mediation, conciliation, voluntary arbitration, fact finding, and compulsory arbitration. Proposals which would solve the problem by amendment to the National Labor Relations Act have been excluded because basic amendments to that act, such as would be accomplished by S. 360 , introduced by Senator Ball, necessarily raise a number of difficult problems which cannot be adequately treated in the space allotted for this discussion.

${ }^{22}$ This type of legislation would prohibit the closed shop, the checkoff, and employer contributions to welfare funds except under specified conditions. Within this group also fall proposals to forbid or control the unionization of supervisory employees.

${ }^{28}$ These proposals would make unions subject to suit in the federal courts for breach of contract, provide penalties for acts of violence during a labor dispute, and amend the National Labor Relations Act to provide for "equality" under the law.

${ }^{24}$ This type of legislation would forbid jurisdictional strikes, boycotts, and other restraints, and strikes over the interpretation or application of the provisions of a collective agreement.

${ }^{15}$ Of the man days lost in work stoppages of 1,000 or more workers from V-J Day to June 30, 1946, $85.9 \%$ were due to disputes over wages and hours. (1946) $63 \mathrm{MO}$. LAB. Rev. 886. While this figure will vary from time to time it does emphasize the relative importance of contract-negotiation disputes.

${ }^{10}$ Unless otherwise indicated all of the bills mentioned herein have becn introduced in the first session of the Eightieth Congress. 


\section{I}

1. President Truman's 2947 Report on the State of the Union. ${ }^{17}$ The President, in the part of his report dealing with labor-management relations, proposed the following four-point program to reduce industrial strife: the enactment of legislation to prevent jurisdictional strikes, unjustified secondary boycotts, and the use of economic force to decide issues arising out of the interpretation of existing contracts; the extension of the facilities within the Department of Labor for assisting collective bargaining; the broadening of the program for social legislation to reduce the causes of workers' insecurity; and the appointment of a Temporary Joint Commission to inquire into the field of labor-management relations.

2. S. 55, The Federal Labor Relations Act of $1947 .^{18}$ This bill, frequently referred to as the Ball-Taft-Smith bill, is a revised version of the so-called Case bill1 ${ }^{10}$ passed by the Seventy-ninth Congress and vetoed by the President. The significant differences between the pertinent provisions of the two bills will be indicated in this discussion of S. $55^{20}$

Title I of the bill is directed to the problem of providing new federal mediation machinery. It would create a Federal Mediation Board in the Department of Labor. The five members of the board would be chosen by the President, with the advice and consent of the Senate, to serve for terms of five years at a salary of $\$ 12,000$ per year. ${ }^{21}$ All mediation and conciliation functions of the Secretary of Labor and all

${ }^{17} 93$ Cong. Rec. 135 (Jan. 6, 1947).

20 Introduced by Senators Ball, Taft, and Smith.

${ }^{10}$ To avoid confusion it seems advisable to review briefly the legislative history of the so-called Case bill and to indicate the terminology which will be used in referring to the various versions of that legislation.

H. R. 4908, the Labor Fact-Finding Boards Act, was introduced in the Seventy-ninth Congress on Dec. 5, 1945. A companion bill, S. 166r, was introduced in the Senate on Dec. 6, 1945. H. R. 4908, with amendments, was reported by the House Committee on Labor on Jan. 28, 1946 (H. R. REP. No. 1493, 79th Cong., 2nd Sess. (1946)). On the floor of the House a bill advocated by Representative Case (S. D.) was substituted for the committee bill and passed with amendments. The Senate Commitree on Education and Labor, to which H. R. 4908 was referred, struck out the provisions inserted by the House, and, on April 16, 1946, reported a bill which had been written in the committee (SEN. REP. II77, 79th Cong., 2nd Sess. (1946)). This bill was amended on the Senate floor, and, as passed by the Senate, resembled the bill which had previously passed the House. The Senate amendments were agreed to by the House on May 29, 1946. President Truman vetoed the bill on June 11, 1946; and an effort to pass it over his veto failed on the same day.

In the Eightieth Congress two bills, similar in many respects to the vetoed bill, have been introduced: S. 55 by Senators Ball, Taft, and Smith, and H. R. 725 by Representative Case (S. D.). The designation H. R. 4908 will be used to indicate the Labor Fact-Finding Boards Act as introduced in the House. The "Case bill" will be used to refer to the version of H. R. 4908 vetoed by the President. S. 55 will refer to the Ball-Taft-Smith version of the Case bill introduced in the Eightieth Congress. H. R. 725 will be used to indicate the labor relations proposal of Representative Case (S. D.) introduced in the Eightieth Congress.

so Title I of S. 55 is comparable to the first six sections of the Case bill.

n $\$ \mathbf{I}(f)$ provides for the appointment of an executive director and such conciliators and mediators as may be necessary. 
the functions, personnel, records, property, and appropriations of the United States Conciliation Service would be transferred to the new board. ${ }^{22}$

The jurisdiction of the board is limited by the bill to disputes in industries affecting commerce. However, this jurisdiction is qualified in two respects. The board is required to avoid mediating disputes having only a minor effect on commerce where state or other conciliation services are available, ${ }^{23}$ and to make mediation and conciliation services available only as a last resort and in exceptional cases in grievance disputes arising over the application or interpretation of a collective agreement. Within these limits the board may proffer its services either upon its own motion or upon the request of one of the parties to a dispute whenever, in its judgment, the dispute threatens to cause a substantial ${ }^{24}$ interruption of commerce.

It is the duty of the board to assist parties to a labor dispute within its jurisdiction to settle the dispute through conciliation and mediation. Where these methods do not result in agreement within a reasonable time, the board is required to attempt to induce the parties to submit their dispute to voluntary arbitration. The board may, on the request of the parties, assist in drawing up the arbitration agreement, in selecting arbitrators, or in making any arrangements necessary to provide for arbitration. Section 2 (c) provides that if arbitration at the suggestion of the board is refused by either party the board must at once notify the Secretary of Labor and the parties in writing that its efforts at mediation and conciliation have failed. The parties are thereupon relieved of their duty under section $3(\mathrm{~b})$ to refrain from engaging in a strike or lockout.

The bill provides that employers and employees in industries affecting commerce shall exert reasonable efforts to make and maintain collective agreements, including provision for adequate notice of change and provision for the final adjustment of grievances on questions regarding interpretation of agreements. They must also arrange for a collective bargaining conference promptly ${ }^{25}$ on request of one of the parties whenever a dispute arises over the terms or application of an agreement, and co-operate fully with procedures undertaken by the board if the dispute is not settled by conference. No sanctions are provided for failure to comply with these provisions.

However, after the board has proffered its services, the parties are required by section 3 (b) to refrain from engaging in a strike or lockout until the board certifies that its efforts at mediation have been concluded or until sixty days from the board's proffer of its services, whichever date occurs first. This provision emphasizes one

sa The board would be in the Department of Labor for housekeeping purposes only. The Bureau of Labor Statistics would be required to maintain files of collective labor agreements and to furnish factual information which might aid in the settlement of any labor dispute. The office of the Solicitor of Labor would be called upon to furnish legal assistance to the board.

2a This limitation was not present in the Case bill.

"The board's interpretation of "substantial" will serve as à further, albeit self-imposed, restraint on its jurisdiction. This concept of a "substantial interruption of commerce" was not in the Case bill.

${ }_{25}$ The Case bill specified that the conference should be held not later than ten days after receipt of written request therefor. 
important difference between $S$. 55 and the Case bill. The latter required the parties to refrain from engaging in a strike or lockout from the time the board proffered its services until it certified that its efforts had been concluded or until sixty days from the giving of notice requesting a collective bargaining conference, whichever date occured first. The parties would therefore have greater control over the period during which they would be required to maintain the status quo under the Case bill than under S. 55 .

Employees who violate section 3 (b) would lose their status as employees for the purposes of sections 8, 9, and ro of the National Labor Relations Act unless reemployed by the employer. An employer who violates section 3 (b) would be guilty of an unfair labor practice within the meaning of section 8 of the National Labor Relations Act. The penalties are exclusive and no other legal or equitable remedy would be available.

The only major provision in that part of the Case bill being considered here which is omitted from S. 55 provided for the appointment of an emergency factfinding commission by the President whenever a labor dispute involving a public utility, whose rates were fixed by a governmental agency, threatened such a substantial interruption of an essential monopolized service as to make it necessary in the public interest to appoint such a commission.

Title II of S. 55 does not fall within the scope of this article. It deals with royalty payments to unions, supervisory employees, union liability for the breach of a collective contract, boycotts, jurisdictional strikes, and registration of labor organizations.

3. S. $73 .^{28}$ This bill is similar to Title I of S. 55. It differs only in that it would establish a Federal Mediation Board completely independent in all respects of the Department of Labor, and in that it would not impose any waiting period while the board attempts to settle a dispute.

4. H. R. 725, The Industrial Relations Act of $1947^{27}$ The provisions of this bill relating to the establishment of machinery for mediation and conciliation, voluntary arbitration, and fact finding ${ }^{28}$ are substantially the same as the comparable sections of the Case bill. ${ }^{29}$ They differ in the following important four respects: the mediation and conciliation functions of the Government are placed by this bill in an Industrial Disputes Commission, completely independent of the Department of Labor; a more formal procedure for voluntary arbitration is established; a broader authority is granted to create fact-finding commissions; and a recommendation by the commission, if accepted by a majority of the employees, becomes binding on both parties for a period of six months from the date of the report. Section 20 of the Clayton $\mathrm{Act}^{30}$ is amended to forbid strikes in an essential monopolized service or industry,

\footnotetext{
${ }^{20}$ Introduced by Senator Morse. $\quad$ Introduced by Representative Case (S. D.).

${ }^{23}$ Title II and $\$ 5301,302(b)$, and 302 (c) of Title III.

30 \$\$1-6. These sections were discussed in connection with S. 55 .

${ }^{20} 38$ STAT. 738 (1914), 29 U. S. C. $\$ 52$ (1940).
} 
which would burden or obstruct commerce in such a way as to endanger the public welfare, health, or safety, after the President has authorized the creation of an emergency fact-finding commission for a particular dispute. ${ }^{31}$

5. S. 404 , The Federal Mediation Act of $1947 .^{32}$ This bill is very similar to S. 55. Its comparable provisions differ in only two significant respects from Title I of that bill. They contain a provision for fact-finding in appropriate cases and establish a sixty-day waiting period in disputes affecting commerce by requiring that the parties incorporate a clause in their contracts which would require a sixty-day notice of any intention to request a change in the terms or conditions of an existing agreement.

6. H. R. 30 . $^{33}$ This bill is similar in many respects to the first six sections of the Case bill. However, there are a number of differences which will be briefly indicated. H. R. 30 r would retain the mediation and conciliation functions of the Government in an expanded and strengthened Conciliation Service in the Department of Labor. A Labor-Management Adyisory Committee would be appointed to advise the Secretary of Labor on labor relations matters and to make recommendations for a permanent panel of arbitrators. Employers and employees in any industry affecting commerce would have the following duties: to exert every reasonable effort to make and maintain agreements concerning working conditions, including provision for notice (ninety days in the case of a public utility and sixty days in other industries affecting commerce) of any proposed change in the terms of such agreement; to submit disputes over the interpretation of the terms of a contract to binding arbitration if not settled by conference; to refrain from strikes or lockouts whenever the Conciliation Service proffers its services until the expiration of the sixty- or ninety-day notice, as the case may be, or until the Director certifies that mediation has failed, whichever date occurs first; and to co-operate with the procedures of the Conciliation Service if the dispute is not settled in conference. An employer who fails to perform any of these duties will be deemed to have engaged in an unfair labor practice within the meaning of the National Labor Relations Act. An employee who fails to perform any of these duties will lose his status as an employee for the purposes of the National Labor Relations Act.

7. H. R. 34, The Public Rights in Labor Disputes Act. ${ }^{34}$ The policy of H. R.

21 It is not clear from the language of $\$ 302$ (b) whether the bill would only forbid a strike in an essential monopolized industry or service when the President has authorized the appointment of a commission to investigate a dispute in that particular industry or service, or whether such a strike would be forbidden whenever any dispute is being investigated by an emergency commission.

s2 Introduced by Senator Ellender.

as Introduced by Representative Smith (Me.).

" H. R. 34 is one of five identical bills introduced in the Eightieth Congress, First Session, by Congressmen Case (N. J.), Herter, Hale, Auchincloss, and Heselton. The other bills are H. R. 17, H. R. 68, H. R. 75, and H. R. 76. Similar bills with two minor differences were introduced in the Seventyninth Congress, Second Session, by the same Congressmen, as H. R. 6912, H. R. 6913, H. R. 6914, H. R. 6915, and H. R. 6916. The bills are based on suggestions made by Professor Sumier H. Slichter, Lamont Professor of Government at Harvard University. Hearings before a Subcommittee of the Commitsee on Labor on H R. 6912, 79th Cong., 2nd Sess. 252 (1946). 
34 is to prevent labor disputes affecting commerce from endangering public health or safety and at the same time to provide additional facilities for the peaceful settlement of labor disputes. To carry out this policy the bill would $(x)$ create an independent agency, the Labor Disputes Conciliation Administration, in which would be vested the mediation and conciliation functions of the Government, (2) establish a Labor-Management Advisory Committee to advise with the Conciliation Administration and to recommend members for an arbitration panel to be maintained by the Conciliation Administration, and (3) require compulsory arbitration of disputes affecting commerce which endanger the public health or safety and which the parties cannot settle by voluntary means.

The Labor Disputes Conciliation Administration would be under the direction of an administrator appointed by the President by and with the advice and consent of the Senate. ${ }^{35}$ The United States Conciliation Service would be abolished and its records and property transferred to the Labor Disputes Conciliation Administration. Thereafter no officer or employee of the Department of Labor would be permitted to perform any conciliation functions in labor disputes.

The agency thus created would have the broad function of offering conciliation services in connection with labor disputes affecting the interests of the public. It would also have the duty of maintaining a permanent panel of arbitrators, composed of not less than thirty individuals, appointed by the President by and with the advice and consent of the Senate.

A Labor-Management Advisory Committee, consisting of seven members representing labor and seven members representing management, would be appointed by the President, by and with the advice and consent of the Senate, to serve on a per-diem basis to advise the administrator with respect to the administration of the act. This committee would also have the duty of recommending a list of qualified persons $^{36}$ from which the President could make nominations to the panel of arbitrators maintained by the Conciliation Administration. The advisory committee would have considerable influence on the selection of individuals to serve on the panel of arbitrators for, while the President would not be required to accept the recommendations of the committee, if he nominated an individual not on the list he would be required to state to the Senate his reasons for believing the individual so nominated to be better qualified than those recommended by the committee.

The compulsory arbitration features of the bill would become operative whenever the President finds that a public emergency ${ }^{37}$ exists or is imminently threatened as

\footnotetext{
${ }^{35}$ The President may appoint as many as three assistant administrators, by and with the advice and consent of the Senate.

${ }^{30}$ The list must contain at least two names for every vacancy on the panel which is to be filled.

" " 33(a) defines a "public emergency" as existing when transportation, public utilities, or communication services essential to the public health or safety, or supplies of articles or commodities cssential to the public health or saftety, have been suspended or substantially curtailed because of a labor dispute affecting commerce (whether or not the parties to the dispute are engaged in furnishing such servicen articles, or commodities).
} 
2 result of a labor dispute affecting commerce, that the public health or safety is endangered thereby, and that local governmental mediation and conciliation facilities have failed or are not available to prevent the work stoppage. The bill provides that, on making such a finding, the President shall issue an order to the parties to the dispute ( $\mathrm{I}$ ) prohibiting the calling or authorizing of any lockout or work stoppage and prohibiting any assistance to the lockout or work stoppage whether by picketing, payment of strike benefits, or otherwise, (2) directing that all lockout or work stoppage orders and authorizations be withdrawn, and (3) directing the parties to refrain from practices which change the situation existing when the dispute arose or which, by changing an existing situation, caused the dispute.

Notwithstanding the provisions of the Norris-LaGuardia Act, ${ }^{38}$ the United States district courts would have jurisdiction, but only on the petition of the Attorney General, to compel compliance with the President's order by injunction, restraining order or other appropriate process.

When the President has issued an order in a public emergency, it would become the duty of the parties to reach a settlement by voluntary means. If they have not settled the dispute or submitted it to voluntary arbitration within thirty days after the issuance of the order, the President would be required, within fifteen days after the expiration of such thirty-day period, to direct that the dispute be submitted to arbitration and that the parties comply with the award.

Each party would thereupon be required to select an arbitrator from a permanent panel of arbitrators maintained by the Conciliation Administration. In case of a refusal to select an arbitrator from the panel, the bill would give the administrator the duty of making a selection for the refusing party. The arbitrators thus chosen would select a third arbitrator, either a member of the panel or some other individual. The award of the arbitration board could be made retroactive and would be binding on the parties for a period of six months unless modified by mutual consent. In determining the character of the award to be made, the arbitrators must take into consideration the fact that the employees' right to strike has been restricted in the interest of the public health and safety; that they therefore should have, in relation to others not so situated, at least as favorable a status in the matter of terms and conditions of their employment. ${ }^{39}$ The award could be enforced in the same manner as an award under the United States Arbitration Act. ${ }^{40}$

8. A System of Labor Courts.11 Under this plan a national system of labor courts would be established which would parallel the present federal court system.

47 Stat. 70 (1932), 29 U. S. C. Sror et seq. (1940).

This provision is the major difference between H. R. 34 and the bills introduced in the Seventyninth Congress mentioned in note 34 , supra.

${ }^{40} 43$ Stat. 883 (1925), 9 U. S. C. S1 et seq. (1940).

${ }^{41} \mathrm{~A}$ bill has been introduced by Senators Ferguson and Smith to establish labor courts in eleven districts with jurisdiction over the interpretation and enforcement of collective bargaining agreements and over interpretation of existing labor laws. Such courts would have no jurisdiction over the bargaining process and no power to end a strike resulting from failure to reach agreement on a contract. $N$. $Y$. Times, March 20, 1947, p. I, col. 4. This summary, prepared before the bill was introduced, is based 
Lay judges would outnumber legal judges by one on each court. All labor contracts affecting interstate commerce would be filed with a district court, and any disagreement over the terms of a contract which could not be settled by the parties would be submitted to the court for final settlement. In disputes involving basic industries or public utilities (such as basic steel, coal, oil, gas, shipping, railroads, electric power, telephone and telegraph), when the parties could not agree upon the terms of a contract, the court would act as a board of arbitration and issue a binding decision. The courts would also have authority to make binding awards in jurisdictional disputes between unions. Court orders would be enforced in two ways: by disbarring any labor or industry representative who defied the court verdict, and by fines against recalcitrant unions or corporations.

9. H. R. 1095, The Industry-Wide Labor Disputes Act of $1947 . .^{22}$ This bill would require that labor disputes be submitted to arbitration if they threaten such an interruption of commerce ${ }^{43}$ as would adversely affect the national health or safety. The refusal of either party to accept the arbitration award would result in federal seizure . and operation of the plant, mine or facility involved in the dispute.

ro. $H . R .787^{44}$ This proposal would permit the Government to seize any plant, mine or facility affected by a labor dispute which the President determines is a threat to the operation of an industry essential to the public health or security and the national economic structure. An employer engaged in a lockout, or officers or agents of a union engaged in a strike or slowdown, would be placed under a duty to take affirmative action to terminate the strike or lockout. A failure to perform this duty would result in a fine or imprisonment. Employees who fail to return to work would lose their status as employees under the National Labor Relations Act or the Railway Labor Act. In addition, the Attorney General would be

upon an article by Senator Ferguson in the February, 1947, issue of the American Magazine, reprinted in 93 Cong. Rec. 291-292 (Jan. 13, 1947).

Gerard D. Reilly, former member of the National Labor Relations Board and former Solicitor of the Department of Labor, has suggested that the National Labor Relations Board, with some changes in its internal structure, could assume the role of a national labor court to prevent activities meeting with the disapproval of Congress. However, unlike most other proponents of compulsory arbitration, Mr. Reilly suggests the doubtful wisdom of requiring arbitration of issues which cannot be settled by reference to the terms of a contract unless Congress at the same time formulates standards for the guidance of the arbitrator. The Washington Sunday Star, Oct. 13, 1946, sec. C, p. 1, col. 1.

12 Introduced by Representative Landis.

${ }^{13} \$_{2}($ b) would define commerce to apply ". . . only! to those businesses, industries, utilities, and activities conducted for private gain, whose productive effort, as distinguished from sales effort or purchases, lies within the jurisdiction of the police power of two or more States, or of the District of Columbia or any Territory of the United States and any State or other Territory, or of any foreign country and any State, Territory, or the District of Columbia, and those businesses, industries, utilitics, and activities conducted for private gain, whose operations were or would have been prior hereto, subject to Federal license, or to the regulation of the Federal Power Commission or the Interstate Commerce Commission." This definition would, upon the passage of this act, become the definition of commerce in all federal acts or parts of acts which govern, regulate, or supervise relations between employers and employees, with the exception of the Railway Labor Act. One obvious result of this provision would be to remove many employees from the protection of the National Labor Relations Act, the Fair Labor Standards Act of 1938 , and many other federal statutes passed for the benefit and protection of employecs.

"Introduced by Representative Smith (Me.). 
authorized to petition the appropriate United States district court for injunctive relief. The seizure order could be nullified by a concurrent resolution passed by the Senate and House of Representatives within ten days of the issuance of the order.

II.

\section{A. Mediation, Conciliation and Voluntary Arbitration Proposals ${ }^{45}$}

I. Administrative Provisions. The question of where the mediation and conciliation functions of the government should be vested has been met in three ways. One bill, H. R. 30r, would keep these functions in the present United States Conciliation Service in the Department of Labor. ${ }^{48}$ S. 55 and S. 404 would create a new Federal Mediation Board, in the Department of Labor for housekeeping purposes only; while H. R. 725, S. 73, and H. R. 34 would place such functions in completely independent agencies. H. R. $30 \mathrm{r}$ and H. R. 34 have two administrative features in common. They would establish a Labor-Management Advisory Committee to advise with the agency invested with the conciliation and mediation functions in labor relations matters, and they would vest such functions in a single individual. Other proposals would place the mediation and conciliation functions in a board or commission.

2. Jurisdiction over Labor Disputes. Only one bill, H. R. 34, would grant jurisdiction over any dispute which has affected or may affect the public interest. The jurisdiction in H. R. 725, S. 73, and H. R. 3 or is limited to disputes in any industry affecting commerce. S. 55 and S. 404 provide that jurisdiction may be assumed whenever a dispute in any industry affecting commerce threatens to cause a "substantial interruption" of commerce, and that mediation should not be attempted whenever the dispute would have only a "minor effect" on commerce. All of the proposals provide that, within the limits set forth in each bill, the agency may proffer its services for conciliation and mediation upon its own motion or upon the request of one of the parties to the dispute.

3. Voluntary Arbitration. If agreement is not obtained by mediation and conciliation within a reasonable time, all of the proposals, with the exception of $H$. $R$. $34,{ }^{47}$ require the administrative agency to seek to induce the parties to submit their dispute to binding arbitration. If arbitration at the suggestion of the agency is refused by either party, the agency is required to notify the Secretary of Labor and the parties that its efforts at mediation and conciliation have failed. This notice releases the parties from the duty to observe any waiting period applicable at that time. In addition to the notice of the failure of mediation and conciliation, H. R.

${ }^{45}$ Bills discussed in this subsection are S. 55, S. 73, S. 404, H. R. 34, H. R. 30I, and H. R. 725.

4" The National Labor Management Conference unanimously recommended ". . . that every effort be made toward the reorganization of the United States Conciliation Service to the end that it be established as an effective and completely impartial agency within the U. S. Department of Labor." The Fresident's National Labor Management Conference, D. L. S. Bull. No. 77 (U. S. Dept. Labor 1946) 48.

${ }^{4}{ }^{7} \mathrm{H} . \mathrm{R} .34$ is primarily intended to provide machinery for compulsory arbitration. 
30 requires that the Director of Conciliation submit a detailed explanation of the positions of the parties in relation to the dispute and the facts relative thereto as found by the Conciliation Service in its conferences with the parties. This report must be published in full by the Secretary of Labor. If the parties accept arbitration, S. 55, S. 404, S. 73 and H. R. 3 or contain provisions requiring the agency to assist, at the request of the parties, in formulating the agreement to arbitrate, in selecting arbitrators, and in making such other arrangements as may be necessary. H. R. 3or would, in addition, establish a panel of arbitrators from which the parties could select an arbitrator or arbitrators if they so desired. If the parties accept voluntary arbitration under H. R. 725, each party is required to select three arbitrators. The six arbitrators thus chosen are then required to select three additional arbitrators from a panel made up of persons appointed by the President and confirmed by the Senate.

4. Waiting Period During Which Parties Must Refrain from Strikes or Lockouts. With the exception of S. 73 and H. R. 34, which do not provide a penalty for engaging in a strike or lockout while the Government is endeavoring to mediate a dispute, all of the proposals have differing provisions on this feature of the settlement machinery. H. R. 725 requires the parties to refrain from engaging in a strike or lockout from the time the board enters the dispute until it notifies the Secretary of Labor and the parties that efforts at mediation and conciliation have failed,.or until sixty days from the request for a collective-bargaining conference, whichever date occurs first. S. 55 has the same provision except that the sixty day period runs from the time the board enters the dispute. In both bills an employer who violates this provision is deemed to have engaged in an unfair labor practice within the meaning of the National Labor Relations Act; an employee who violates the provision will lose his status as an employee within the meaning of that Act unless he is re-employed by the employer. S. 404 would require the parties to include in all future collective contracts, covering employees in industries affecting commerce, a provision for sixty days' notice of any intent to change the terms of the agreement. The contract must also provide that, if notice is not given sixty days prior to the termination date, the contract will remain in effect until sixty days after notice is given; that, for the first thirty days of the sixty-day notice period, the parties will engage in collective bargaining in good faith; and that, if unable to reach an agreement within that period, they will submit the issues still in dispute to the board of conciliation and mediation. Employers who refuse to incorporate such provisions in their contracts or who fail to carry out such provisions will be deemed to have engaged in an unfair labor practice, and similarly recalcitrant employees will lose their status as such under the National Labor Relations Act. This proposal also places a duty upon employers and upon union officials and agents to take affirmative action to rescind or terminate any strike or lockout during the waiting period which was called at their instance or with their consent. Willful violation of this provision 
will bar the individual, for one to five years, from acting as a collective bargaining representative of any employer or employee, or from serving as an officer in any corporation engaged in an industry affecting commerce, or from serving as an officer of any labor organization representing employees in an industry affecting commerce.

H. R. 3 or would require the parties to provide in their contracts for a sixty-day notice of any proposed change in the terms of the agreement; ninety days would be required in the case of a public utility. The bill would also require the parties to refrain from engaging in a strike or lockout whenever the Conciliation Service proffers its services and until it certifies that its efforts have failed or until the expiration of the sixty- or ninety-day period, whichever date occurs first. Violation of either provision by an employer would be an unfair labor practice. An employee guilty of a violation would lose his status as an employee under the provisions of the National Labor Relations Act.

\section{B. Facr-Finding Proposats ${ }^{48}$}

I. Authority to Use the Fact-Finding Procedure. The fact-finding procedure tends to be limited to the most important disputes. H. R. 4908 would have granted the President authority to establish a fact-finding board whenever the Secretary of Labor certified that a labor dispute seriously threatened the national public interest. H. R. 30I, which has the same provisions for fact-finding as were contained in the Case bill, would limit the President's authority to disputes involving a public utility whose rates are set by a governmental agency. In such a dispute the President would be authorized to create an emergency commission after the Secretary of Labor has determined that the dispute threatens a substantial interiuption of an essential monopolized service. S. 404 and H. R. 725 not only contain broader provisions for the use of fact-finding, but they also provide that the necessary finding shall be made by the President without first requiring any recommendation from an official experienced in labor relations problems. The President would have authority, under S. 404, to create a fact-finding commission when he makes a finding that a dispute in an essential industry threatens to result.in such interruptions to the supply of goods or services essential to the public health or security as seriously to endanger the public welfare. The provisions of H. R. 725 authorize the President to create an emergency fact-finding commission under the following circumstances: at the request of the parties to any labor dispute affecting commerce; whenever he determines that any labor dispute endangers the public welfare, health, or safety; ${ }^{49}$ or whenever the Industrial Disputes Commission reports that a dispute affecting commerce threatens a substantial interruption of an essential monopolized service.

2. Duties and Powers of the Fact-Finding Commission. H. R. 725, H. R. 30I,

${ }^{68}$ The bills discussed in this subsection are S. 404, H. R. 4908, H. R. 725 , and H. R. 30r. H. R. 4908, the Labor Fact-Finding Boards Act, while not before the present Congress, contains several provisions which are not found in the other bills and therefore adds to the discussion of the fact-finding technique.

"The authority under this clause is not limited to disputes "affecting commerce." 
and S. 404 contain similar provisions on this point. All would require the commission to investigate the facts in the dispute and report within thirty days. The recommendations would be limited to wages, hours, and working conditions but the report could describe other issues involved in the dispute. The report would be made public by the President. H. R. 4908 differs in two important respects. Under it the commission would be authorized to investigate all the facts which it deemed relevant to the dispute and to submit findings of fact and such recommendations as it deemed appropriate. It would also be clothed with the power of subpoena. In all bills the time for submitting the report could be extended by agreement of the parties and with the permission of the President. With the exception of H. R. 725, the statutory procedure would end with the submission of the report of the commission; it would then be up to the parties to accept or reject the recommendation. However, H. R. 725 provides that the recommendations of the commission shall be binding on both parties in any of three situations: when accepted by them, or when accepted by an employer and the representatives of the employees, or when accepted by a majority of the employees in a secret vote. The balloting would be conducted by the National Labor Relations Board, when requested by the President, if the union representatives have not accepted the recommendations of the commission within five days after the report is filed. If a majority of the employees accept the recommendations, they become binding on both parties for a period of six months from the date of the report.

3. Duties of Employers and Employees. All of the bills require the parties to maintain the status quo from the time of the appointment of the fact-finding commission. The waiting period runs until the submission of the commission's report in S. 404, until five days after submission of the report in H. R. 725 and H. R. 4908, and until fifteen days after submission of the report in H. R. 30r. S. 404 also places a duty upon the employer and union officials or agents to take affirmative action to stop any strike or lockout during the waiting period which is called at the instance or with the consent of such employer, officer, or agents. Except for H. R. 4908, which provides no sanctions, the bills uniformly punish a failure to maintain the status quo during the waiting period by making the employer subject to an unfair labor practice charge before the National Labor Relations Board and by denying an employee the protection of the National Labor Relations Act unless he is reemployed by his employer. The willful failure of an employer or a union official or agent to carry out the duty to take affirmative action imposed by S. 404 would result in his being prohibited, for one to five years, from acting as a representative of any employer or employees in an industry affecting commerce, from serving as an officer in any corporation engaged in an industry affecting commerce, or from serving as an officer of any labor organization representing employees in an industry affecting commerce. H. R. 725 carries an additional feature not found in any of the other fact-finding bills. It would amend the Clayton Act ${ }^{50}$ to make a

${ }^{80} 38$ STAT. 738 (1914), 29 U. S. C. 552 (1940). 
strike illegal in an essential monopolized service or industry, if it results in placing a burden on commerce endangering the public health, welfare, or safety, after the President has authorized the creation of an emergency fact-finding commission for a particular labor dispute..$^{51}$ Violators of this provision would be subject to civil or criminal action by the Attorney General under the provisions of the Clayton Act.

\section{Compulsory Arbitration Proposals ${ }^{52}$}

r. Jurisdiction of Arbitration Boards. Proposals which would settle labor disputes by compulsory arbitration limit that procedure in general to cases in which a finding has been made that the dispute threatens a substantial interruption of an industry vital to the public health, safety, or welfare. In H. R. 268 and H. R. 34 the finding must be made by the President; in $\mathrm{H}$. R. 1095 it must be made by the President and the Secretary of Labor or the President and the governor of any affected state. The jurisdiction of the labor courts to deal with collective-bargaining disputes would be limited to basic industries and public utilities engaged in interstate commerce.

2. Compulsory Arbitration Procedures. H. R. 268 employs a fact-finding procedure. After the President has made the necessary finding, he would appoint a commission to investigate the dispute and to make a recommendation. The parties must accept this recommendation as a basis for settlement. When the necessary finding is made under the provisions of $H$. R. I095, the parties are required to submit the dispute to a board of arbitration. If either party rejects the decision of the board, the Government is authorized to seize the plant, mine, or facility. A rejection by the employees must be ratified by a majority of the employees in an election. H. R. 34 allows the parties thirty days, after the Presidential finding and order, to settle the dispute by mediation, conciliation, or voluntary arbitration. If those procedures fail the President must, before the expiration of fifteen additional days, direct the parties to submit their dispute to an arbitration board. ${ }^{53}$ The labor court proposal would require the parties to submit their dispute to a three-judge district labor court.

3. Duties and Penalties. Under the provisions of H. R. 268 the parties in any dispute covered by the bill must refrain from engaging in a strike or lockout; they are also required to accept the recommendation of the fact-finding commission as a basis for the settlement of the dispute. Failure to observe these provisions will cause an employer or a labor organization to lose all rights under any federal laws regulating labor relations and subject them to a fine in an amount to be determined

¿2 Note 31, supra.

82 The proposals discussed in this subsection arc H. R. 34, H. R. 268, H. R. 1095, and the labor court system advocated by Senator Ferguson.

${ }^{83} \mathrm{H}$. R. 34 is the only proposal which attempts to give special consideration to employees who have been deprived of the right to strike. $\$ 7(c)$ requires the board of arbitration to consider their special status in determining the award and provides that employees subject to the Act ". . . ought to have, in relation to others not so situated, at least as favorable a status in the matter of the terms and conditions of their employment." 
by a court. An employee who goes on strike would lose his status as an employee under the National Labor Relations Act, and even if rehired would lose all seniority rights. H. R. I095 provides for seizure of the plant, mine, or facility if either party refuses to submit the case to arbitration, fails to maintain the status quo while the board is reaching a decision, or refuses to accept the award of the board. Possession of the plant, mine or facility by the Government may not be retained in any case for more than one year, and the property must be returned at the end of any sixtyday period of non-profitable operation. If the seizure has been caused by the actions of the employees, they would lose their status as employees under the National Labor Relations Act after ninety days of Government possession; if it has not been caused by the actions of the employees, the Government would retain all operating profit during the period of seizure. When the President makes the necessary finding under H. R. 34, he also issues an order requiring the parties to maintain the status quo. Such order may be enforced by appropriate process issued by a district court of the United States on the petition of the Attorney General. Any representative of labor or management who defies the verdict of a labor court would be prohibited from reappearing before the court; unions or employers refusing to abide by the labor court's decrees would be subject to a fine.

With the exception of those proposals which rely on compulsory arbitration or on the outright denial of the right to strike (as in H. R. 787), the bills which have been discussed would make but two substantial changes in the machinery and procedures now being used to minimize mass work stoppages resulting from the failure to settle labor contract negotiation disputes by collective bargaining. ${ }^{54}$ The first would place the mediation and conciliation functions in a new independent agency; the second would implement the mediation and fact-finding procedures by imposing a waiting period before the parties could engage in a strike or lockout.

The provisions for the establishment of a Labor-Management Advisory Committee and a panel of impartial arbitrators are not as comprehensive on these points as the recommendations of the National Labor-Management Conference.55 Pursuant to those recommendations, a Labor-Management Advisory Committee, appointed by the Secretary of Labor from nominations submitted by labor and management groups, was established and has been meeting with the Director of Conciliation to advise and actively participate in all major policy processes in the Conciliation Service. In addition, a Technical Advisory Committee has been established, composed of appointees nominated by labor and management, to advise on problems

st Any matters within the jurisdiction of the Railway Labor Act would be exempt from the provisions of H. R. 30r, H. R. 4908, the Case bill, and S. 73; they would be exempt from the mediation, conciliation, and arbitration features of S. 55, H. R. 725, and S. 404, but not from the other features of those bills. They would not be exempt from the provisions of H. R. 34, the labor court proposal, H. R. 268, H. R. 1095 , or H. R. 787 .

${ }^{56}$ D. L. S. Bull. No. 77 , cited supra, note 46 , at $47-49$. 
relating tó wage incentives, job evaluations, time studies, and similar technical matters.

Other steps which have been taken to strengthen the Conciliation Service and which are not set forth in any of the proposed bills include the establishment of regional advisory committees to advise with the regional directors of the Conciliation Service and to pass upon the competency and impartiality of the panel of arbitrators maintained in each region; the establishment of a panel of twenty-six nationally known experts on labor relations to act as special conciliators to be assigned to disputes when their special background qualifies them to handle a particular case; and the establishment, on an experimental basis, of a labor-management assembly consisting of outstanding individuals representing labor and management to help promote good labor relations in their local areas. 